\title{
Indonesia Tourism Enterprises' Stock Returns Research: Looking Back and Moving Forward
}

\author{
Subur Karyatun ${ }^{1}$, Mahlia Muis², Abdul Razak Munir ${ }^{2}$, Sumardi², Kadek Wiweka, ${ }^{3,4 *}$ \\ ${ }^{1}$ Faculty of Economic and Business, Hasanuddin University \& National University, Indonesia \\ ${ }^{2}$ Faculty of Economic and Business, Hasanuddin University, Indonesia \\ ${ }^{3}$ École Doctorale Sociétés, Temps, Territoires (EDSTT) Tourisme, Université Angers, France \\ ${ }^{4}$ Department of Research, Sahid Polytechnic, Indonesia
}

Received December 14, 2021; Revised January 24, 2022; Accepted February 16, 2022

\section{Cite This Paper in the following Citation Styles}

(a): [1] Subur Karyatun, Mahlia Muis, Abdul Razak Munir, Sumardi, Kadek Wiweka , "Indonesia Tourism Enterprises' Stock Returns Research: Looking Back and Moving Forward," Universal Journal of Accounting and Finance, Vol. 10, No. 2, pp. 527 - 537, 2022. DOI: 10.13189/ujaf.2022.100217.

(b): Subur Karyatun, Mahlia Muis, Abdul Razak Munir, Sumardi, Kadek Wiweka (2022). Indonesia Tourism Enterprises' Stock Returns Research: Looking Back and Moving Forward. Universal Journal of Accounting and Finance, 10(2), 527 537. DOI: 10.13189/ujaf.2022.100217.

Copyright $\odot 2022$ by authors, all rights reserved. Authors agree that this article remains permanently open access under the terms of the Creative Commons Attribution License 4.0 International License

\begin{abstract}
The objective of this research is to compare movement of stock return literature on companies in the tourism sector and other businesses. This study also analyzed comprehensively the relationship between contexts built on the literature. The mix method approach is adopted by combining text mining methods, which are analyzed using network and content analysis methods. The scientific literature was collected using the web scraping method on Litmaps and selected 200 articles and only used 195 articles (between 2000-2021) related to the topic of stock returns and 23 (between 2013-2020) related to the tourism company sector. In the process of data analysis and visualization, this study uses AntConc, RStudio, and Gephi software. This review discovered that in terms of topic and context, stock return studies discuss issues related to the influence of fundamental factors on stock returns, and vice versa, while the approach used is mostly quantitative based on the financial performance reports. Regarding the frequency of appearance, this result revealed that the effects of fundamental factors on stock returns in tourism companies can be translated into a number of strategic issues, including Current Ratio, TATO, ROE, FATO, and Systematic Risk, which provide a significant and positive effect on Direct Share Prices. Furthermore, the Current Ratio, TATO, ROE, and FATO are thought to have a significant and positive effect on stock returns via Systematic Risk. The scope of this research is limited to the
\end{abstract}

national journal (Indonesia) on the Litmaps search engine. In theory, the results of this research can be used as a comparison and considerations related to previous studies, as well as what investigation requires to be done immediately, in the context of tourism companies' stock returns. The literature study on the tourism companies' stock returns issue is perhaps the first systematic literature review in Indonesia.

Keywords Stock Return, Tourism Companies, Literature Review, Text Mining, Network Analysis

\section{Introduction}

The tourism industry has proven to play an important role in the global economy, at least just before the COVID-19 virus outbreak reached numerous countries worldwide (1). Statista (2) mentions that, from 2000 to 2019, tourism has contributed directly to world GDP, with an average growth rate of $10 \%$. However, the crisis that occurred in approximately all sectors of the country has had a substantial effect on negative growth in the last 20 years. According to WTTC (3), the Travel \& Tourism sector lost nearly US $\$ 4.7$ trillion in 2020, with the sector's GDP contribution dropping dramatically by 49.1 
percent as compared to 2019. Furthermore, 62 million jobs, or 18.5 percent, will be lost by 2020. The decline in expenditure influenced this phenomenon for domestic visitors by $45 \%$, while the expenditure for international visitors fell by an unprecedented $69.4 \%$.

A comparable case is experienced by the tourism industry in Indonesia. Since 2008, this sector has played a significant role in the economy, particularly through exchange rates, which has continued to rise steadily until 2019. According to the Central Bureau of Statistics (4), currency exchange growth has averaged more than $10 \%$ since 2008. In the meantime, the tourism exchange rate is expected to begin the year with a 14 percent deficit, which is expected to worsen as COVID-19 spreads throughout the country (5).

This record demonstrates how important the tourism sector is to the economic and financial sector. Despite the fact is that this innovative industry is frequently regarded as a delicate business. However, this sector can present difficulties, particularly in the petroleum industry (6). Therefore, shares of tourism and hospitality sector companies are often the choice for investors.

COVID-19 had an impact on investment conditions in Indonesia in general. The IDX (Indonesia Stock Exchange) reported that the Indonesia Composite Index (7) fell 26.43 percent to 4.635 until the close of trading on April 17, 2020, followed by a 26.11 percent drop in market valuation to IDR 5.368 trillion. Furthermore, the average daily intensity fell 1.49 percent to 462 thousand times, while the average daily trade balance fell 23.84 percent to IDR 6.34 trillion. Uncertainty drove this negative trend and occurs in almost all industrial sectors, including tourism. Referring to IDX data (7), the tourism industry is categorized as a service company with trade, service, and investment sectors, which comprise the hotel, restaurant, and tourism sub-sector (94).

The investment itself is one factor that plays an essential role in destination growth $(8,9)$. However, (10) explains that estimating stock market returns in large sectors such as tourism and hotels is one of the key challenges in the financial economy. The predictability challenge in the shares of tourism and hospitality companies shows how this business has an acute sensitivity to systemic risk. Therefore, the understanding of predicting returns on tourism and hotel stocks, which are often dominated by systematic uncertainty, is a very crucial issue to study. The problematic issue of macroeconomics is predicting stock returns derived from existing monetary factors that represent stock return risk.

Investment theory asserts that securities, one of which stocks, will generate returns and risks $(11,12)$. The outcome of an investment is referred to as its return. Meanwhile, the risk seems to be the difference between the expected and realized returns on these securities $(13,14)$.

There are many studies examining stock price behavior, and they frequently pay close attention to the connection between the stock market and macroeconomic factors (15). However, studies in the tourism studies that focus on macroeconomic factors and stock returns are scarce. Some of these case studies are also limited to regions such as China, Taiwan, Kenya, and several countries in Europe and the United States (16). Several studies have also found that returns on shares in hospitality and tourism companies are considered abnormal (17).

In Indonesia, based on the search for stock returns and tourism keywords in the Litmaps search application (18), it shows that this issue only began to be studied in the early 2000s, while for the tourism sector it has only been recorded that it has only been researched since 2013. This phenomenon illustrates those academics, researchers, and tourism stakeholders have not explored massively macro-economic issues, particularly those related to stocks. This theoretical fact is in stark contrast to the empirical fact that tourism has long been an important sector of the Indonesian economy.

As a result, the purpose of this review is to look into the evolution of stock return research in Indonesia, particularly in the tourism market. Furthermore, the purpose of this research is to compare trends in the literature on stock returns in tourism sector companies and other sectors in contexts of the issues covered and the framework used. This investigation also thoroughly examined the relationship between contexts based on the literature. The literature study on stock returns in tourism companies is perhaps the first systematic literature review in Indonesia. Therefore, the results are expected to provide a comprehensive picture of stock returns, particularly in the tourism sector. Tourism stakeholders and general investors can also use this research to understand the characteristics of stock returns in the tourism sector, which are different from other industries.

\section{Literature Review}

\subsection{Tourism Companies}

According to Tourism Law No. 10 of 2009, a tourism business is one that generates goods and/or services for visitors and coordinates the travel industry (9). A tourism entrepreneur, on the other hand, is a person or an organization who engage in tourism business operations $(19,20)$. This law also describes tourism businesses which comprise tour guides, tourist attractions (21-23), tourism areas, tourist transportation, tour travel, food and beverage $(5,24,25)$, accommodation (26), entertainment, and recreation activities, MICE (27), tourist information services, tourism consultant, marine tourism, and spas.

However, as it develops, the tourism industry becomes much more complex than what is governed by government regulations. Tourism is now not only associated with local communities $(22,28,28-31)$, local 
wisdom (32), destination, and natural potential (33,34), but it has also permeated technology issues, investment, millennial tourists (35-37), and startups (38).

Meanwhile, based on IDX data (7), tourism is categorized (39) into the industrial sector (C) or service companies, the hotel, restaurant, and tourism sub-sector (94).

\subsection{Stock Returns}

The value of financial gain or income obtained from investing in share securities investment instruments is referred to as stock return (40). Meanwhile, the other researchers (41) add that returns can be classified based on actual cash value that has already taken place or expected returns which have not yet occurred. The realized profit or historical return is indeed very essential for measuring the firm's productivity (42) and is vital in evaluating the projected risk and return in the long run. The expected return is the return expected by investors in the future. Dividends and capital gains/losses can be obtained as a result of share ownership. The distinction in profit (loss) from the current funding price relative to the previous period's price is referred to as capital gain/loss.

Sudarsono and Sudiyatno (43) observed that many factors determine stock returns, including fundamental and technical information. Furthermore, several macroeconomic factors arising from diverse economic problems, such as economic policy, inflation, interest rates, currency exchange rates, and people's incomes, play a significant role. As a result, the use of models becomes critical in understanding stock prices and assisting investors in effectively planning and deciding their investments.

\subsection{Literature Review}

The Litmaps search engine is used to find literature for this study, which is then critically reviewed using a literature review approach. This approach is a critical analysis method of stock returns through various literature sources (44). This approach is quite popular and has been used in the tourism sector to examine issues of cultural tourism, sustainable tourism, and tourism information technology (45).

\subsection{Text Mining, Network Analysis, and Content Analysis}

This study also employs a text mining technique called Knowledge Discovery in Databases (KDD). This approach was chosen because the main data used were text-based scientific articles (46). This method is carried out in two phases. The first is processing and integrating unstructured data. Second, analyzing statistical data generated by content extraction from the text (46).

Meanwhile, the network analysis method which is part of the Social Network Analysis is used to analyze the relationships (edges) between words (nodes) through graphical software visualization. The engine analysis output (in this case, the AntConc, RStudio, and Gephi software) is then interpreted through content analysis, which is able to comprehensively dissect data statistics (47).

\section{Methods}

The qualitative method (48) approach was adopted in this study by combining text mining methods (quantitative). Meanwhile, this study used a network analysis method and content analysis of articles on stock market returns in the tourism industry and other sectors to analyze the results of text analysis (see Figure 1). Information from the articles is then extracted based on the topic aspects and approaches using text mining techniques. First, articles as data were collected using the web scraping method on Litmaps, which is a scientific literature search tool with the keywords stock return and tourism (see Figure 2). Furthermore, AntConc software is used to process text mining to produce output as terms frequency, clusters/N-Grams, while RStudio software is used to produce word clouds (49). The output data is then treated as nodes and edges in network analysis using Gephi software and completed by qualitative content analysis. 


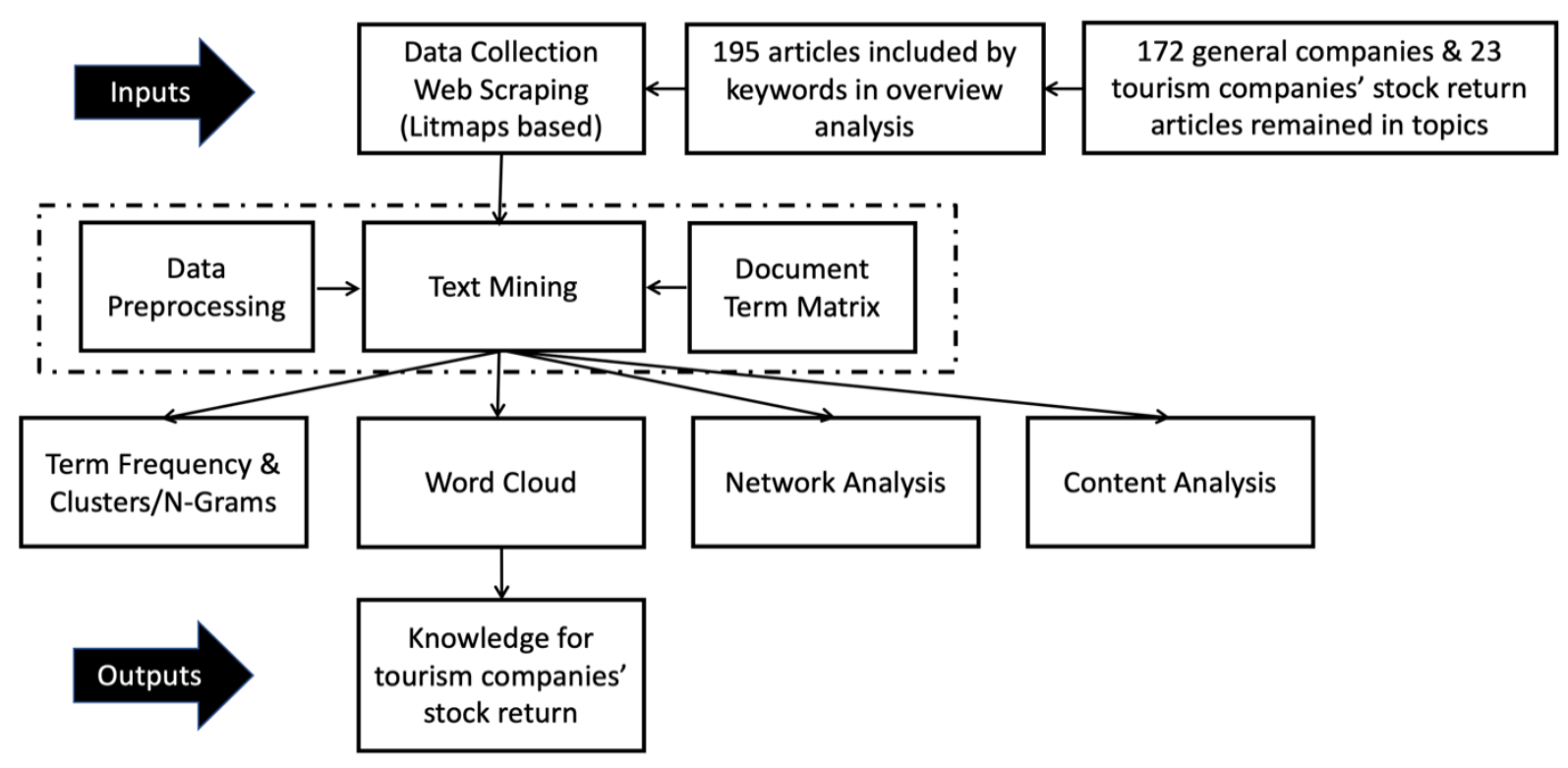

Source: The author's own study, 2021

Figure 1. Text mining flow chart

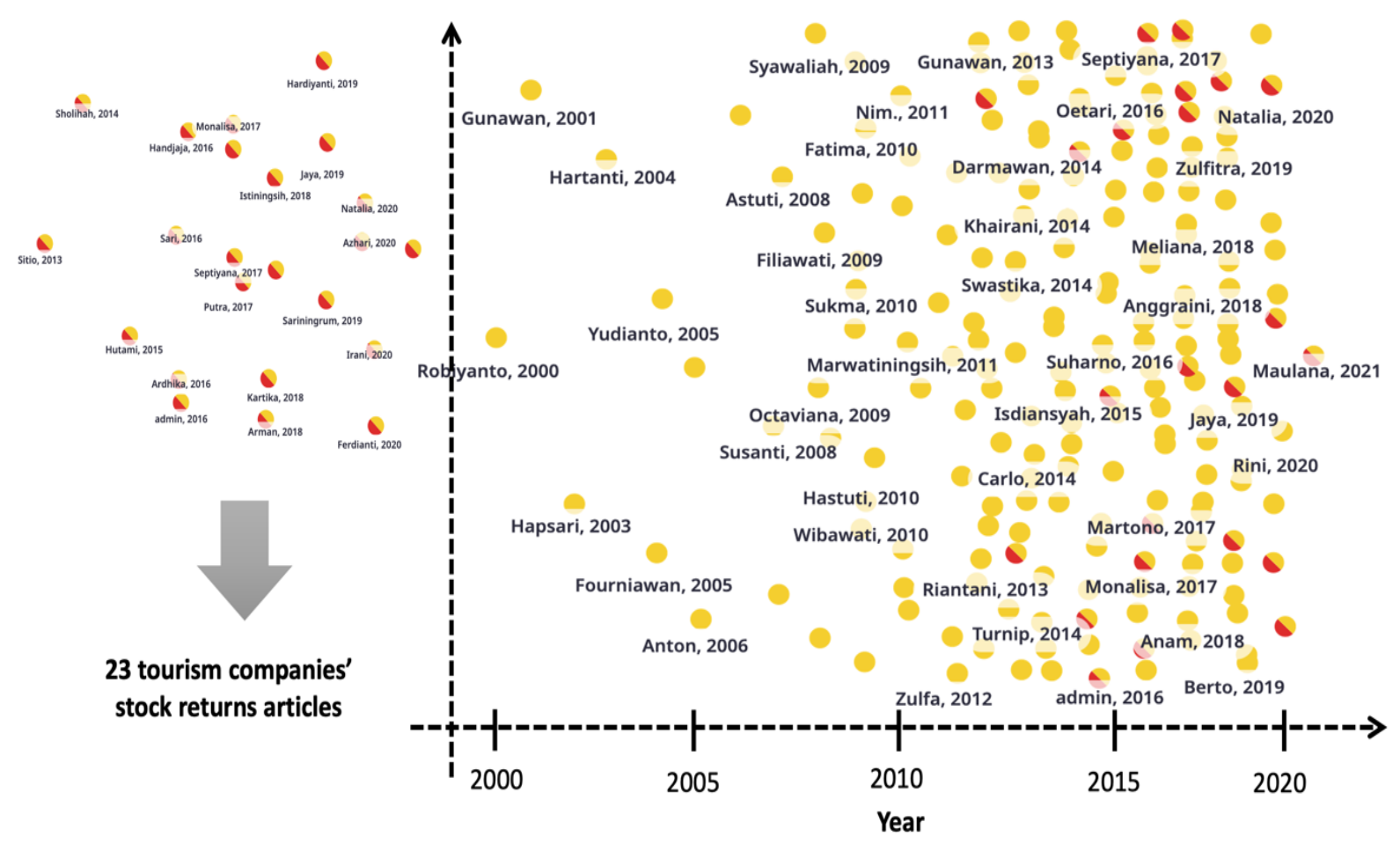

Source: The author's own study, 2021

Figure 2. The distribution comparison of scientific literature based on the topic of stock returns in the tourism sector and other sectors

\subsection{Data Collection and Text Mining}

The search results on Litmaps show 200 scientific articles related to the keyword. However, the selection process reduced to 195 (between 2000-2021) related to the topic of stock returns, and only 23 (between 2013-2020) discussed the tourism company sector. The keywords "stock return" and "tourism" must at least appear in the title, abstract, or keywords. The web scraping stage extracts aspects of titles, research approaches, and research discussions. For the purposes of the text mining and analysis process, these data tabulations are then stored in text format (txt.) And categorized based on the topics and aspects studied.

Text mining in data collection is carried out in two 
phases, data preprocessing and document term matrix (DTM). Data cleaning, data aggregation, data conversion, and normalization are all examples of data preprocessing. Unneeded or meaningless words are cleaned, while some parts that are eliminated include punctuation, emoticons, lowercase, remove tags (URL), white space, and numbers. The next step is to remove the stop-word, stemming, lemmatization, and standardize the typo word (slang word). The data is then converted into text (txt.) and excel (xlsx.) formats. Tokenization and normalization are also carried out and evaluated continuously.

The Document Term Matrix (DTM) was also created to describe the common words, terminology, or tokens in the dataset. The AntConc device is used to identify frequencies and clusters (50).

\subsection{Term Frequency and Cluster/N-grams}

Term frequency is analyzed through a word list tool that calculates all words in the tourism companies' stock return corpus. The results of the analysis found 946-word lists (tokens) which are then treated as nodes (visual representations of an entity, in this study, are words) and 1,745-word pairs (n-grams or common expressions in the corpus) as edges (a visual representation of a relation, in this case, a line connecting two nodes), for network analysis.

\subsection{World Cloud Technique}

The processed text data (DTM) is then represented visually as a Word cloud (51). The RStudio tool (52) is then used to visualize the frequency of appearance of words freely based on scales and grouped by topic and aspect. The four corpuses used have been categorized based on the topic of stock returns to tourism companies and other public companies, as well as the two aspects, namely topic or context and approach. The commands used to generate data are as follows.

\#Generate the Word cloud

set.seed(1234)

wordcloud(words $=\mathrm{d} \$$ word,freq $=\mathrm{d} \$$ freq, min.freq $=$ 3 , max.words $=70$, random.order $=$ FALSE, rot.per $=$ 0.65 , colors = brewer.pal(6,"Dark2"))

Word cloud has a minimum word frequency of 3 and a maximum number of words displayed randomly of 70 .

\subsection{Network and Content Analysis}

The Gephi open-source application is used for network analysis, which comprises a process of visualization, exploration, and manipulation of a word network (token). The network property statistical calculations analyzed include Network Diameter, Average Degree Distribution, and average path length. Meanwhile, modularity is used to visualize clusters (see Figure 5) in a network. The next stage is a content analysis carried out to interpret and describe the frequency patterns and relationships that have been visualized through RStudio and Gephi devices. This analysis also uses several supporting references related to stock returns.

\section{Result and Discussion}

\subsection{Corpus Profile}

The review shows that studies related to stock returns in Indonesia have only been carried out since the early 2000s and have increased significantly from 2010 to 2020. Meanwhile, specifically, the topic of stock returns in the tourism sector only emerged in 2013 and increased in 2016. Although since 2013 there have only been 23 pieces of literature examining tourism companies' stock returns. However, this reference is very important to understand the characteristics or research patterns of stock returns in this significantly growing industry in Indonesia. The distribution of the two topics in the literature is depicted in the figure 2 .

In a broader sense, the distribution of movement described above is a positive sign for the tourism industry, which is recognizing the significance of investment in the tourism development business (9). Specifically, the Ministry of Tourism and Creative Economy is supporting government programs to increase the contribution of tourism sector investment to total national investment and the development of Special Economic Zones (SEZ) (53).

\subsection{The Current Trend of Indonesian Tourism Companies' Stock Returns Research}

This study will then compare patterns or characteristics between research on stock returns on the topic of companies in the tourism sub-sector and other general sectors. In this phase, all literature on both topics will be treated as a corpus that is analyzed and categorized based on aspects of the topic or context and approach. This review uses DTM as word frequency as the output of the text mining process, which is visualized using RStudio software and analyzed qualitatively. 


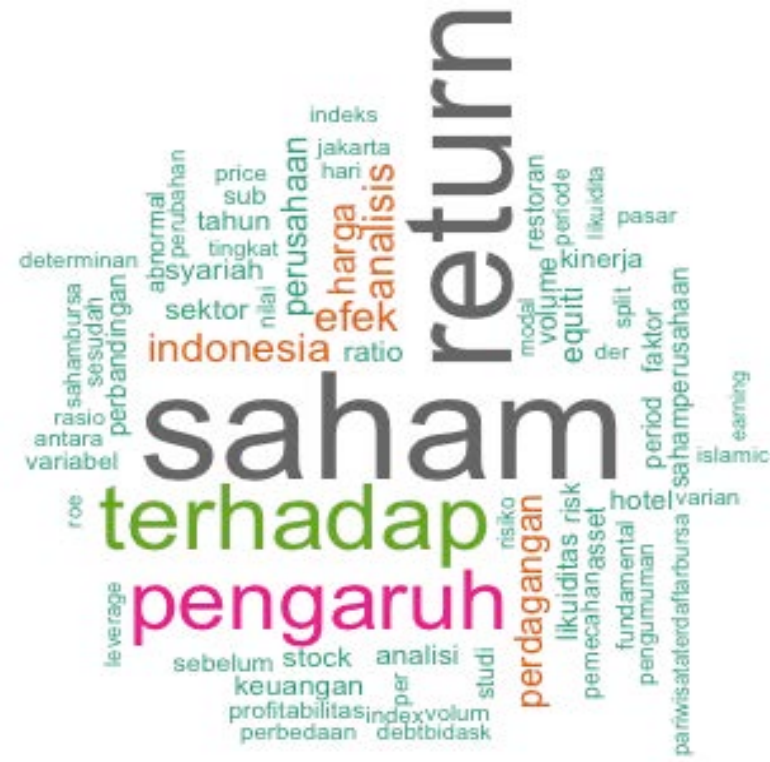

Other sectors

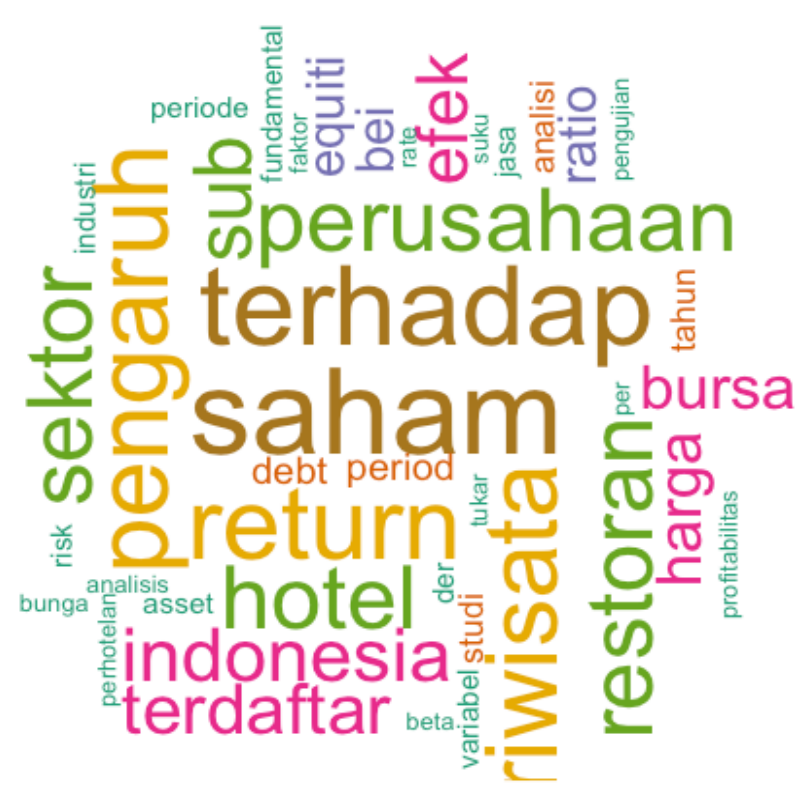

Tourism sector

Source: The author’s own study, 2021

Figure 3. Article topic word cloud result

\subsection{Stock Return Topic and Context in the Tourism Sector}

Figure 3 shows that the two topics appear to have identical research scopes following a review of the literature title. This argument is supported by the calculation of the 20 highest frequency tokens that show only a slight difference. However, seen from the word-list of the two topics, the difference is only in the frequency number of the appearance of the words. One of the significant differences in the scope of research on the topic of tourism companies' stock returns, which seems to be more focused on companies in the tourism sector, such as hotels and restaurants. The 20 tokens with the highest frequency in the company sub-sector other than tourism include stocks (saham, 327), return (return, 232), influence (pengaruh, 121), company (perusahaan, 64), analysis (analisis, 56), Indonesia (Indonesia, 45), effect (efek, 43), stock exchange (bursa, 41), price (harga, 33), trading (perdagangan, 33), lq (lq, 28), sharia (syariah, 27), listed (terdaftar, 27), equity (equity, 25), study (studi, 24), volume (volume, 24), liquidity (likuiditas, 23), factor (faktor, 22), tourism (pariwisata, 21), and period (periode, 21). Whereas in the tourism sub-sector, they are stocks (saham, 23), tourism (pariwisata, 21), influence (pengaruh, 19), return (return, 19), hotels (hotel, 17), restaurants (restoran, 17), companies (perusahaan, 16), sector (sektor, 16), sub (sub, 14), Indonesia (Indonesia, 13), listed (terdaftar, 13), stock exchange (bursa, 12), securities (efek, 12), price (harga, 10), BEI (bei, 8), equity (equity, 8), period (periode, 8), ratio (ratio, 8), analysis (analisis, 6), and debt (debt, 5). The frequency of occurrence of this word is then visualized into the word cloud as shown in figure 3.

The word cloud indicated that the main topics' research areas are mostly associated with the subject of the effect of several fundamental factors on stock returns or vice versa, on the corporate financial performance identified on the IDX. These factors include Current Ratio (CR), Return on Asset (ROA), trade volume, Return on Equity (ROE), Debt to Equity Ratio (DER), Price Earnings Ratio (PER), Total Assets Turnover (TATO), Return on Investment (ROI), systematic risk, Leverage, market value, stock price, exchange rate, Price Book Value (PBV), Investment Opportunity Set, Dividend Payout Ratio (DPR), Economic Value Added (EVA), Net Profit Margin (NPM), Basic Earning Power (BEP), Stock Split, stock liquidity, and profitability.

While companies that are listed on the IDX and are often reviewed are Sharia-based companies, food and beverage, trading sector companies, services, and investment, manufacturing, mining, banking, plantations, hotels, restaurants, and tourism.

\subsection{Approach in Tourism Companies' Stock Returns Research}

Figure 4 shows that the literature focusing on tourism companies and other general companies does not show a significant difference based on the analysis of the research approach. Although seen from the word-list with the highest frequency on the two topics, it looks a little different. However, this difference is because of the frequency number of occurrences of words which, when viewed comprehensively or as a whole word-list, can be said to be identical. 

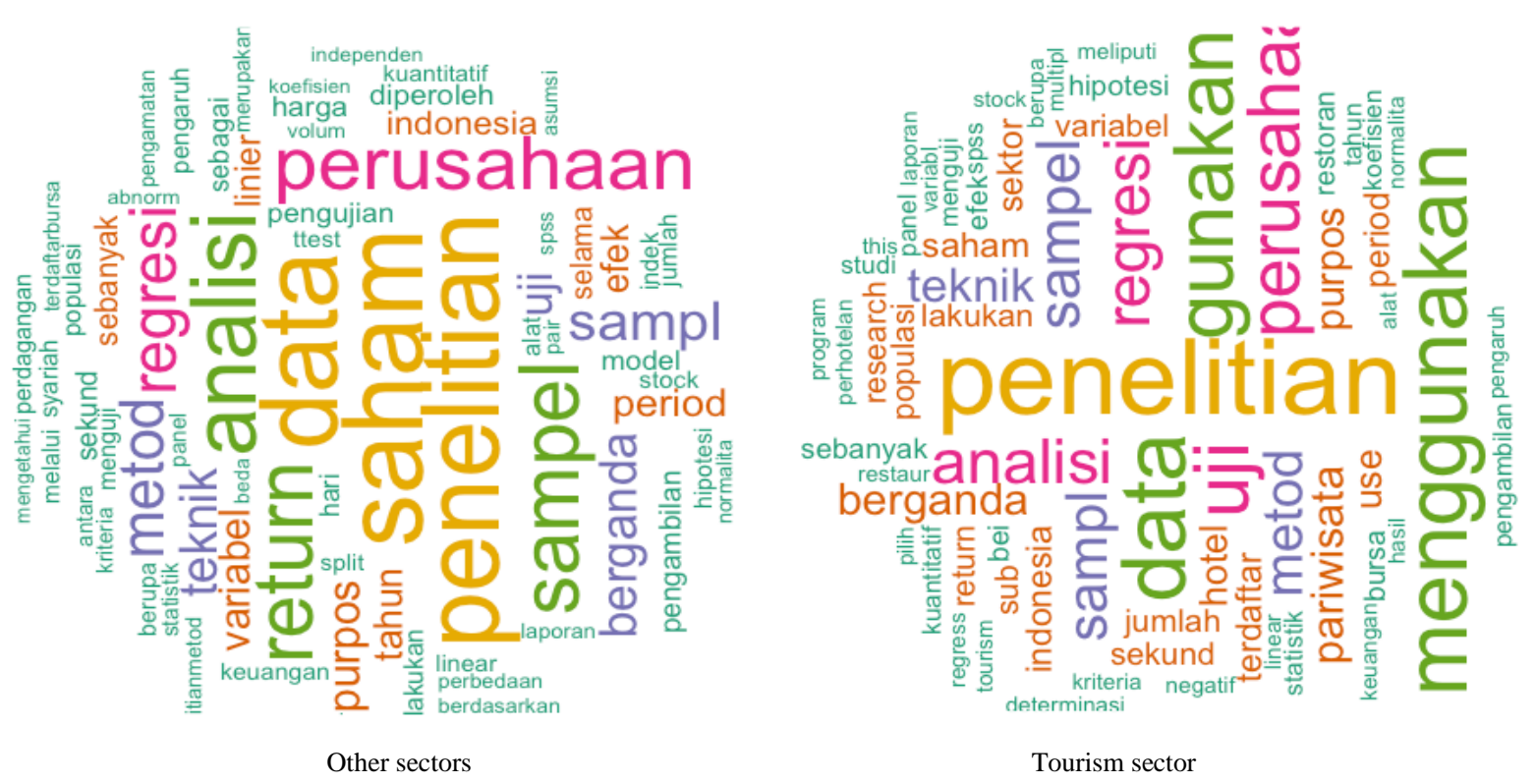

Source: The author's own study, 2021

Figure 4. Research approaches word cloud result

The term frequency statistics show that the 20 tokens with the highest frequency on company topics other than tourism include research (penelitian, 238), stocks (saham, 227), data (data, 207), analysis (analisis, 167), sample (sampel, 146), return (return, 133), test (uji, 133), company (perusahaan, 130), method (metode, 129), regression (regresi, 104), technique (teknik, 73), multiple (berganda, 72), sampling (sampling, 63), purposive (purposive, 61), variable (variabel, 61), period (periode, 46), obtained (diperoleh, 45), effect (efek, 41), Indonesia (Indonesia, 41), and hypothesis (hipotesis, 38). Whereas on the topic of tourism companies including research, (penelitian, 30), data (data, 24), test (uji, 22), company (perusahaan, 19), regression (regresi, 16), analysis (analisis, 15), sample (sampel, 15), method (metode, 13), technique (teknik, 13), r (r, 11), sampling (sampling, 11), multiple (berganda, 10), tourism (pariwisata, 10), purposive (purposive, 9), hotel (hotel, 7), Indonesia (indonesia, 7), linear (linier, 7), stock (saham, 7), sector (sektor, 7), and sub (sub, 7). The results can then be illustrated as shown in figure 4 .

The word cloud above demonstrates that, in terms of research methodology, the two topics use nearly identical approaches and methods. Most of the literature uses a quantitative approach to analyze the effect of stock returns on fundamental factors or vice versa. The statistical method that is quite familiar to use on this topic is a regression, which has been very effective for analyzing the influence between two or more variables (54). In the case of stock returns, this method is often used to design estimates, test hypotheses, and predict the value of a variable. In addition, several methods are also used on this topic, including Autoregressive Integrated Moving Average (ARIMA), market and adjusted, cross sectional, Moderated Regression Analysis (MRA), event study, comparative descriptive, Fourier series, Partial
Adjustment Model (PAM), Vector Error Correction Model (VECM), Path Analysis with Structural Equation Modeling (SEM), and Modeling of Stock Return Volatility.

The statistical test procedures used include heteroscedasticity test, the coefficient of determination (R2), the T-test, Analysis of variance (ANOVA), F-test, multicollinearity test, the classic assumption test which comprises normality test, Wilcoxon Match Pair Test, and autocorrelation test. While analysis tools that are also widely used include the Statistical Package for Social Science (SPSS) and Excel. Most of the literature also uses stock data on companies listed on the IDX (7) as the population or sample used.

\subsection{Comprehensive Network Analysis of Stock Return Issues in Tourism Companies}

The network property statistical review of the stock return dataset of tourism companies found that the resulting Average Degree Distribution value was 3.941, while the weight of the Average Weighted Degree was 4.027. This statistic implies that the higher the value, the more connections one node has to other nodes on a network. Meanwhile, the next measurement is to identify the diameter of the text network or Network Diameter (55). This method is done by looking for nodes that have the farthest linkage. Based on the review, this topic has a Network Diameter of 13 with a radius of 1 , and an average distance between nodes or an average path length of 4.33 (55). Meanwhile, the calculation of the Modularity score is 0.58 with a Modularity resolution of 1 , and the cluster that is in the network or number of communities is 17. The Yifan Hu layout is used in this study to visualize the network analysis, which has 946 nodes and 1.745 edges between nodes. 


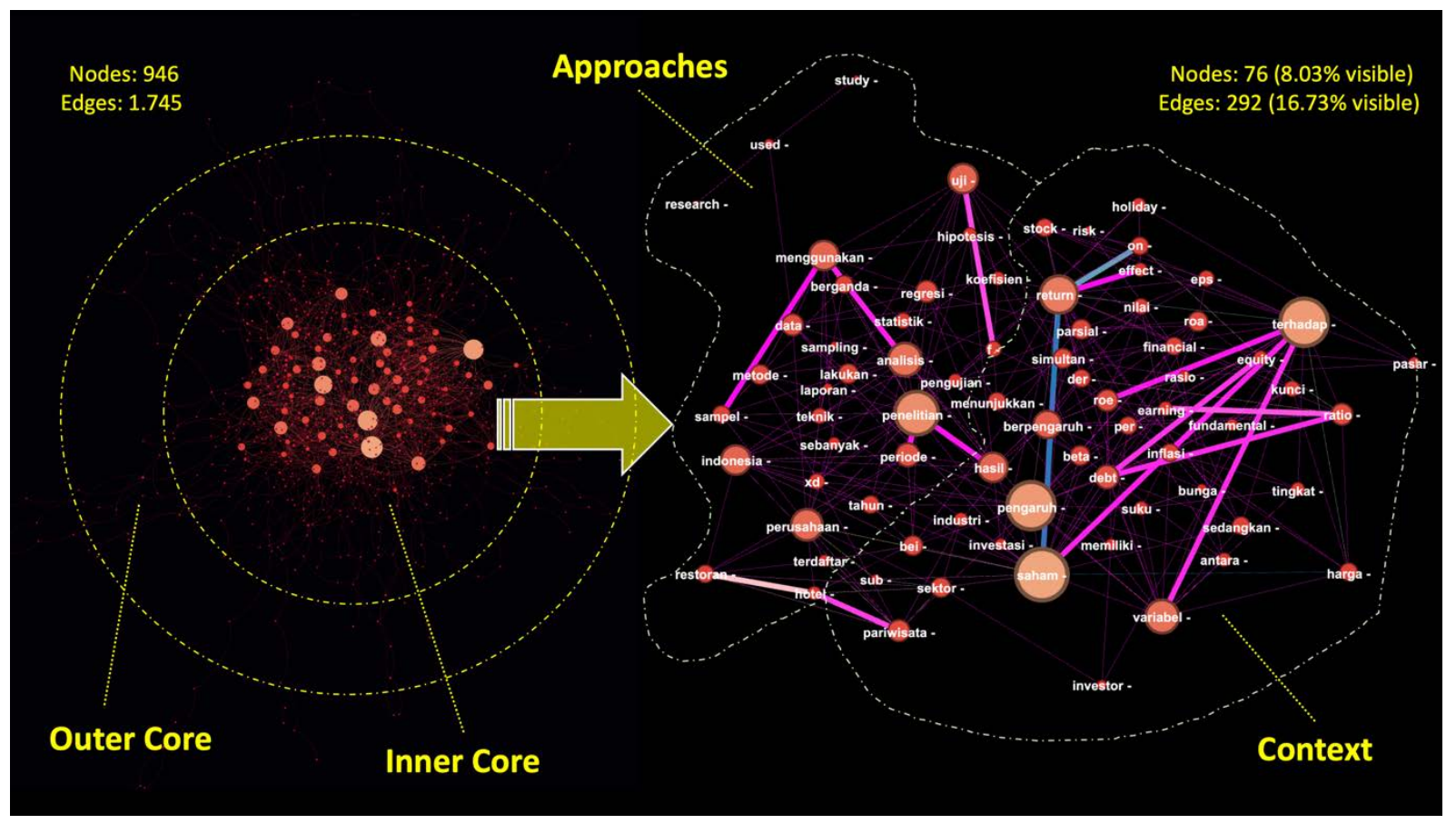

Source: The author’s own study, 2021

Figure 5. Text network analysis of Indonesia’s tourism companies' stock returns research.

Figure 5 shows that the results of the network analysis found that the correlation between nodes was divided into two network clusters. Clusters with a high frequency of occurrence of nodes and an enormous weight of edges can be grouped as inner cores. This cluster is a visualization of the main issues that are most widely discussed on the topic of stock returns in tourism companies. On the other hand, clusters with low frequency and low edge weight can be grouped as outer cores. This cluster represents the issues that are least discussed in the literature on the same topic.

This review also shows that the inner core network consists of context and approach aspects. Meaning, these two aspects represent the two focuses of the review of the literature used. These two aspects also have different weights of nodes and edges, which are shown by the scale of the size of the circle and connecting lines. The thicker the line connecting the two nodes and the bigger the circle, the bigger the weight or degree it has. In short, it can be said that large-scale nodes and edges are an issue that is often discussed and become the essence of the topic of stock returns in tourism companies. This visualization is then clarified by assigning nodes' labels to each of the nodes, which are indicated by the token identity. These tokens or nodes represent an issue that is often discussed in the literature.

According to the definition, the stock market is the amount of profit or income earned from making an investment through share securities investment instruments. Thus, the visualization of the network analysis above is contextually related to investment or economic sectors. Therefore, some nodes that appear are familiar terminology used in the context of investment and stocks.

The review shows that the context built is related to the influence of several fundamental factors on stock returns and vice versa on the financial performance of tourism companies. Some factors that appear in the visualization include dividend payout ratio, Return on Equity (ROE), Price-Earnings Ratio (PER), Price Book Value (PBV), Current Ratio (CR), Investment Opportunity Set, Return on Investment (ROI), Debt to Equity Ratio (DER), and beta. While regression to measure the influence of two or more variables is a common approach in this type of study. The statistical test procedures that are also frequently used include the F-test. However, this statistical testing approach and procedure was not the only one adopted. Figure 4 shows several other statistical test approaches and procedures that are also used in the tourism companies' stock returns literature in Indonesia, although they are not dominant in terms of frequency number.

Therefore, this study confirms that the visualization that appears in network analysis is a representation of issues that are often discussed. However, this review does not place low frequency as a less important issue. Perhaps these issues (outer core) are an area of study that has not been widely explored or is an approach that is rarely used. This cluster may actually need more attention in future research.

Based on the framing context of network analysis and supported by various stock returns in literature, this study develops a comprehensive eight-point framework for the impact of fundamental factors on stock market returns in Indonesian tourism companies. These points include: the 
current ratio has a direct and significant positive impact on stock performance; TATO has a direct and significant positive impact on stock returns; ROE has a direct and significant positive impact on stock return; FATO has a direct and significant positive impact on stock returns; systematic risk has a direct and significant positive impact on stock returns; through Systematic Risk, Current Ratio and TATO have a positive and significant effect on Stock Return; through Systematic Risk, ROE has a positive and significant effect on stock return; through Systematic Risk, FATO has a positive and significant effect on stock returns.

\section{Conclusions}

This study concludes that the investment issue in the tourism sector is getting academics or researchers' attention, both from the fields of tourism and economics. This trend is a positive indicator, mainly because of the government's vision to increase the contribution of tourism sector investment to total national investment, including through the development of Special Economic Zones (SEZ). Academics' involvement in scientific studies is undoubtedly anticipated and vital to the program's development.

In terms of topic and context, studies on stock returns address issues concerning the impact of underlying factors on stock returns and vice versa. Some of the most frequently discussed fundamental factors include dividend payout ratio, beta, Price-Earnings Ratio (PER), Price Book Value (PBV), Return on Equity (ROE), Investment Opportunity Set, Return on Investment (ROI), Debt to Equity Ratio (DER), and Current Ratio (CR). Conversely, several factors that have not been studied much include Total Assets Turnover (TATO), Return on Assets (ROA), systematic risk, Basic Earning Power (BEP), Economic Value Added (EVA), trading volume, Stock Split, stock liquidity, profitability, rupiah exchange rate, Net Profit Margin (NPM), leverage, market value, and price shares. The majority of the case studies use a quantitative approach and financial performance reports from firms mentioned on the IDX. Based on the problem statements that frequently arise, this study concludes that the impact of fundamental factors on stock returns in Indonesian tourism enterprises can be divided into several strategic issues, such as Current Ratio, TATO, ROE, FATO, and Systematic Risk have a direct and significant impact on stock returns. Furthermore, Current Ratio, TATO, ROE, and FATO are thought to have a significant and positive effect on stock returns via Systematic Risk.

In theory, the findings of this study can be used as a reference and considerations related to previous studies, as well as what investigation needs to be accomplished, in the stock returns of tourism enterprises. Meanwhile, the practical benefit of this research is the fact that tourism companies' stock returns are very difficult to predict and have an acute sensitivity to systemic risk. Therefore, this literature can provide comprehensive information in analyzing the stocks of hospitality and tourism companies, which are often considered abnormal. The sample size of this study is limited to the national (Indonesian) journals available on the Litmaps search engine. Therefore, in the future, research with a wider literature source is highly desirable. In addition, the eight points concluded in this study can also be used as hypotheses and continued through comprehensive and in-depth research, especially related to tourism sector companies.

\section{Acknowledgements}

There are no conflicts of interest associated with this publication, nor is there any substantial financial contribution for this work that might have impacted its overall result. As Corresponding Author, I verify that the manuscript has been read and endorsed for submission by all of the named authors.

\section{REFERENCES}

[1] UNWTO. Tourism and COVID-19 - unprecedented economic impacts | UNWTO [Internet]. 2021 [cited 2021 May 2]. Available from: https://www.unwto.org/tourism-a nd-covid-19-unprecedented-economic-impacts

[2] statista.com. Travel and tourism: share of global gdp 2000-2019 [Internet]. Statista. 2021 [cited 2021 May 2]. Available from: https://www.statista.com/statistics/109993 3/travel-and-tourism-share-of-gdp/

[3] WTTC. Economic Impact [Internet]. 2021 [cited 2021 May 2]. Available from:https://wttc.org/Research/Economic-Im pact

[4] BPS. Jumlah Devisa Sektor Pariwisata, 2015-2018 [Internet]. 2020 [cited 2020 Dec 11]. Available from: https://www.bps.go.id/dynamictable/2018/05/22\%2000:00 :00/1357/jumlah-devisa-sektor-pariwisata-2015-2018.html

[5] Wachyuni SS, Wiweka K. THE CHANGES IN FOOD CONSUMPTION BEHAVIOR: A RAPID OBSERVATIONAL STUDY OF COVID-19 PANDEMIC. 2020;

[6] Napierala T, Szutowski D. The impact of localized innovations on the stock returns of tourism companies. Int $\mathrm{J}$ Tour Res. 2019;21(1):108-21.

[7] www.idx.co.id. PT Bursa Efek Indonesia [Internet]. 2021 [cited 2021 May 3]. Available from: https://www.idx.co.id /perusahaan-tercatat/profil-perusahaan-tercatat/detail-profil e-perusahaan-tercatat/?kodeEmiten=ABMM

[8] Aratuo DN, Etienne XL. Industry level analysis of tourism-economic growth in the United States. Tour Manag. 2019;70:333-40.

[9] Wiweka K, Arcana KTP. Rethinking the Theory of Tourism: What is Tourism System in Theoretical and Empirical 
Perspective? J Bus Hosp Tour. 2019;5(2):318-36.

[10] Jiang Y, Tian G, Wu Y, Mo B. Impacts of geopolitical risks and economic policy uncertainty on Chinese tourism-listed company stock. Int J Finance Econ. 2020;

[11] Huy DTN, Nhan VK, Bich NTN, Hong NTP, Chung NT, Huy PQ. Impacts of Internal and External Macroeconomic Factors on Firm Stock Price in an Expansion Econometric model-A Case in Vietnam Real Estate Industry. In: Data Science for Financial Econometrics. Springer; 2021. p. 189-205.

[12] Pástor L, Veronesi P. Political cycles and stock returns. J Polit Econ. 2020;128(11):4011-45.

[13] Bhamra HS, Uppal R, Walden J. Psychological distance and deviations from rational expectations. Working paper; 2021.

[14] Rouwenhorst KG. 10 Asset Pricing Implications of Equilibrium Business Cycle Models. In: Frontiers of business cycle research. Princeton University Press; 2021. p. 294-330.

[15] Diep HT, Desgranges G. Dynamics of the price behavior in stock markets: A statistical physics approach. Phys Stat Mech Its Appl. 2021;570:125813.

[16] Jareño F, Escribano A, Torres MP. Analysis of stock returns of main European service and tourism companies. Tour Econ. 2021;1354816621992983.

[17] Jawed MS, Vinod Tapar A, Dhaigude AS. Crisis, firm characteristics and stock performance: evidence from Hospitality and Tourism sector. Tour Recreat Res. 2021;118.

[18] Litmaps. Litmaps [Internet]. Litmaps. 2021 [cited 2021 May 29]. Available from: https://app.litmaps.co

[19] Indrajaya T, Cahyandito MF, Wiweka K, Adnyana PP. The development of creative industry strategies as a tourist attraction in Banten Province, Indonesia. J Econ Manag Trade. 2019;1-10.

[20] Indrajaya T, Kartini D, Kaltum U, Mulyana A, Wiweka K. An Exploratory Study of the Influence Between Stakeholders Orientation, Strategic Capabilities, and Shared Value Creation towards Competitiveness through Digital Business Strategies in Banten Cultural Tourism Destination. Syst Rev Pharm. 2021 Mar 26;12(3):647-62.

[21] Wiweka K, Indrajaya T, Wachyuni SS, Adnyana PP, Hanorsian AE. Opportunities and Challenges for the Development of Sustainable Tourism Attraction at Batu Kapal Beach, Central Maluku Lilibooi Village. Adv Res. 2019;1-14.

[22] Wiweka K, Demolingo RH, Karyatun S, Adnyana PP, Nurfikriyani I. TOURIST VILLAGE REJUVENATION AND OVER-TOURISM MANAGEMENT: THE DESA WISATA NGLANGGERAN LIFECYCLE EXPERIENCE, YOGYAKARTA, INDONESIA. Tour Hosp Rev. 2021 Feb 8;8(1):01-16.

[23] Arcana KTP, Wiweka K. A study of indigenous tourism product development case study: The Baduy, South Banten, West Java. J Ilm Hosp Manag. 2016;7(1):65-74.

[24] Wachyuni SS, Wiweka K, Softia I. AN EMPIRICAL STUDY OF FOOD BLOGGER INFLUENCE ON
COFFEE SHOP BRAND IMAGE AND CONSUMER PURCHASE DECISION IN DELAPAN GRAM. J BuS Hosp Tour. 2021;7(3).

[25] Wachyuni SS, Demolingo RH, Wiweka K. Gastronomy Tourist's Experience: Evidence from Gudeg "Yu Djum” Yogyakarta. TRJ Tour Res J. 2021;5(2):118-33.

[26] Wiweka K, Arcana K. The impact of tourist accommodation development toward the socio-cultural aspects in the seminyak village, district of kuta, regency of badung, bali (in Perspective of the Local Community). In: Asia Tourism Forum 2016-the 12th Biennial Conference of Hospitality and Tourism Industry in Asia. Atlantis Press; 2016.

[27] Arcana KTP, Wiweka K. The Impact of Managing Sustainable Event and the Contribution to the Formation of Destination Image at Nusa Dua Resort, Bali. J Ilm Hosp Manag. 2015;6(1):43-8.

[28] Arcana KTP, Wiweka K. The Potential Development of Community Based Tourism at Ambengan Village, Buleleng Regency, Bali. J Bus Hosp Tour. 2015;1(1):11.

[29] Arcana KTP, Wiweka K. THE PERCEPTION OF LOCAL COMMUNITY TOWARD TOURIST ACCOMMODATI ON DEVELOPMENT, CASE STUDY: VILLAGE OF SEMINYAK, BALI. J Bus Hosp Tour. 2016;2(1):442-57.

[30] Setiawan B, Wiweka K. A study of the tourism area life cycle in Dieng Kulon village. Pertanika J Soc Sci Humanit. 2018;26(T Apr):271-8.

[31] Setiawan B, Arief M, Hamsal M, Furinto A, Wiweka K. Local's Perspective of Community Participation in Lake Toba as a Tourism Destination. Solid State Technol. 2020;63(4):1124-32.

[32] Demolinggo RH, Damanik D, Wiweka K, Adnyana PP. SUSTAINABLE TOURIST VILLAGES MANAGEMENT BASED ON JAVANESE LOCAL WISDOM 'MEMAYU HAYUNING BAWONO' BEST PRACTICE OF DESA WISATA PENTINGSARI, YOGYAKARTA. Int J Tour Hosp Rev. 2020 Nov 17;7(2):41-53.

[33] Parantika A, Wibowo FS, Wiweka K. The Development of Thematic Tourist Village of Mulyaharja Bogor Based on Community Empowerment Approach. TRJ Tour Res J. 2020;4(2):113-32.

[34] Demolingo RH, Moniaga NEP, Karyatun S, Wiweka K. Homestay Development Strategies in Cibodas Village. 2021;

[35] Setiawan B, Trisdyani NLP, Adnyana PP, Adnyana IN, Wiweka K, Wulandani HR. The Profile and Behaviour of 'Digital Tourists' When Making Decisions Concerning Travelling Case Study: Generation Z in South Jakarta. Adv Res. 2018 Nov 13;1-13.

[36] Damanik D, Wachyuni SS, Wiweka K, Setiawan A. The Influence of Social Media on the Domestic Tourist's Travel Motivation Case Study: Kota Tua Jakarta, Indonesia. Curr J Appl Sci Technol. 2019 Aug 9;1-14.

[37] Wiweka K, Wachyuni SS, Simawang SP, Adnyana P, Wihartaty E. Current Issues of Backpacking Tourism Development: Profile and Characteristics of "Sharecost" and "Opentrip” Tourist. J Educ Soc Behav Sci. 2019 Apr 19;1-12. 
[38] Yenny M, Wiweka K, Wachyuni SS, Adnyana PP. How are Holiday Photography Startups "Disrupting” Indonesia Tourism Business? South Asian J Soc Stud Econ. 2020;6277.

[39] Maharani AD, Febriani FR, Khorismawati NF, Wijaya JH. Analysis of the Impact of Covid-19 on the Performance of Tourism Sector Companies in IDX for the Period 2019-2020. Solid State Technol. 2020;63(3):4503-9.

[40] Janskỳ P, Palanskỳ M. Estimating the scale of profit shifting and tax revenue losses related to foreign direct investment. Int Tax Public Finance. 2019;26(5):1048-103.

[41] Gormsen NJ, Lazarus E. Duration-driven returns. Available SSRN 3359027. 2019;

[42] Subiyanto B, Awaludin DT, Demolingo RH, Ifani R, Wiweka K. EXPLORING THE EFFECT OF CORPORATE SOCIAL RESPONSIBILITY, LEVERAGE, AND IN ${ }^{\text {TEL }}$ LECTUAL CAPITAL ON FINANCIAL PERFORMANCE (EMPIRICAL EVIDENCE FROM BANKING SECTOR COMPANIES PERIOD 2015-2019). 2021;

[43] Sudarsono B, Sudiyatno B. Faktor-faktor yang mempengaruhi return saham pada perusahaan property dan real estate yang terdaftar pada bursa efek indonesia tahun 2009 s/d 2014. J Bisnis Dan Ekon. 2016;23(1).

[44] Booth A, Sutton A, Papaioannou D. Systematic approaches to a successful literature review. 2016;

[45] Niñerola A, Sánchez-Rebull M-V, Hernández-Lara A-B. Tourism research on sustainability: A bibliometric analysis. Sustainability. 2019;11(5):1377.

[46] Loureiro SMC, Guerreiro J, Ali F. 20 years of research on virtual reality and augmented reality in tourism context: A text-mining approach. Tour Manag. 2020;77:104028.

[47] Qian J, Shen H, Law R. Research in sustainable tourism: A longitudinal study of articles between 2008 and 2017. Sustainability. 2018;10(3):590.

[48] Jonker J, Pennink B. The essence of research methodology: A concise guide for master and $\mathrm{PhD}$ students in management science. Springer Science \& Business Media; 2010.

[49] Ainin S, Feizollah A, Anuar NB, Abdullah NA. Sentiment analyses of multilingual tweets on halal tourism. Tour Manag Perspect. 2020;34:100658.

[50] Anthony L. AntConc (Windows, Macintosh OS X, and Linux). Recuperado Httpwww Antlab Sci Waseda Ac JpsoftwareREADME AntConc3. 2011;2.

[51] Salloum SA, Al-Emran M, Monem AA, Shaalan K. Using text mining techniques for extracting information from research articles. In: Intelligent natural language processing: Trends and Applications. Springer; 2018. p. 373-97.

[52] Team RC. R: A language and environment for statistical computing. 2013;

[53] Kemenparekraf, Baparekraf. Siaran Pers: Menparekraf Undang Investor Tanam Modal di KEK Likupang [Internet]. Kemenparekraf. 2021 [cited 2021 May 3]. Available from: https://www.kemenparekraf.id

[54] Prabowo TF. Analisis hubungan kepemilikan asing, pengungkapan emisi karbon, dan return saham. SKRIPSI-2019. 2019;

[55] Jackson MO. Social and Economic Networks, Princeton, NJ: Princeton Univ. Press; 2008. 